\title{
Faculty Development - Needs, Priorities and Preferences in Health Professions Education - Questionnaire-Based Descriptive Study
}

\author{
Philipraj, S.J. ${ }^{1}$ \& Rudravaram, R.V. ${ }^{2}$
}

\begin{abstract}
Introduction: Instructors in the health professions today must acquire knowledge and competencies. The domains necessary are teaching, assessment, curriculum support, organizational leadership, and mentoring. Most Health professions Educational Institutions support faculty development programs as a way of providing opportunities for professional and personal growth in knowledge, skills, motivation, attitude, and innovation.
\end{abstract}

Method: This is a Questionnaire based study. Two sets of questions were prepared. Questions were validated and assessed for reliability.

Total Number - 640, Administrators - 120, Faculty- 520

Result: Number of responses recorded - 423/640 (66.09\%), Faculty - 349/520 (67.11\%), Administrators $-74 / 120(61.66 \%)$.

Faculty; It is clear that only roles of teacher and presumed benefits of FDP's were observed to be significant. Significance is noticed in items roles of teacher and Newer contents of FDP. The respondents who had attended $\mathrm{MCl}$ have opinionated that it is the role of the teacher to fulfil the FDP and there are some newer content areas that should be covered in FDP.

Administrators; only significance is noticed with respect to the respondents who had attended $\mathrm{NCl} / \mathrm{DCl}$ and they felt that it is better to organize FDP's. Clinical faculty felt that specialized FDP's are to be organized.

Conclusion: The need for faculty development is universal and it is clear by the responses given by the faculty.

Keywords: Faculty, Administrators, Faculty Development Programme (FDP), Attitude, Perception, Pedagogy.

\section{Introduction}

Faculty are the greatest "Human Resource" who teach knowledge and skills to students in an educational organization.

${ }^{1}$ Department of urology, Mahatma Gandhi Medical College and Research Institute, Sri Balaji Vidyapeeth, Puducherry.

${ }^{2}$ Department of Statistics, Pondicherry University, Pondicherry.

Corresponding Author:

Dr.S.Joseph Philipraj

Professor, Department of urology, Mahatma Gandhi Medical College and Research Institute, Sri Balaji Vidyapeeth, Puducherry.

Email: josephphilipraj@gmail.com
Health professions faculty were often not trained in education and primarily delivered content via lecture, a method that research suggests is not the best way to engage students and promote knowledge retention (Sutkin, 2008; Swanwick, 2008).

Faculty development is the key component of medical education. The primary purpose of Faculty Development programs is to improve skills in instructions and professionalization of the educational activities of health professionals in colleges of medicine, dentistry, pharmacy, nursing, physical therapy, and other health professions schools (Laura, 2007; Hauer, 2008; Stritter, 1983). This will obviously benefit students and improve their performance. Many studies have reported on the characteristics of effective medical teachers

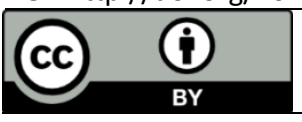

44 
(Leslie, 2013; Paul, 2006). Some of the commonly cited characteristics include content expertise, excellent communication skills, a non-judgmental personality, and good mentorship. There is increasing demands on medical teachers to be creative and effective teachers, successful investigators, and productive clinicians. These pressures have been derived from contemporary curriculum development, competition in the health care institutions, and from the limited resources for research. All these have emphasized that such changes entailed faculty members to attain new knowledge, diverse skills, and abilities in many aspects including, managing multiple roles and new responsibilities like clinical instruction, micro-group teaching, problem-based tutorials, case-based discussions, become mentors, and develop and evaluate new curricula.

Faculty members need to be prepared enough by faculty development program (FDP) in order to deal with the rapid changes and shifting paradigms in medical education, health care delivery systems, and clinical practice. Without such training, medical teachers are often reduced to instructors presenting their understanding of the subject by one-way lecturing. The concept of faculty development in higher education was started by Gaff in 1975 (Gaff, 1975). These included all those activities that were to help teachers to improve their teaching skills, design improved curricula, and enhance the organizational climate for education. Stritter described setting up individual consultations on teaching skills, curriculum design, and collaborative educational research (Stritter, 1983). Most Medical and Health professions Educational Institutions support faculty development programs as a way of providing opportunities for professional and personal growth in knowledge, skills, motivation, attitude, and innovation. The impact of these programs on respective institutions is unknown because sound evaluation procedures to measure their outcomes have been lacking. WHO in its mandate has emphasised the need for focusing on all health professions beyond traditional silos, with emphasis on medicine, nursing, and public health- Health Professionals for a New Century: Transforming Education to Strengthen Health Systems in an Interdependent WorldOct 2011. Goal is to create transformative and interdependent professional education for equity in health. In order to achieve this, WHO has envisaged few reforms in Health education.
Instructional:

- Competency-driven

- Local responsiveness with global connectivity

- Inter- \& trans-professional education

- IT-empowered

- Educational resources

- New professionalism

\section{Institutional:}

- Joint planning

- Academic systems

- Global networks

- Culture of critical inquiry

In view of this, the NEED BASED faculty development programmes (FDP) are essential and the opinion from faculty and administrators should be solicited to plan for future FDP's. Our study is done to assess the attitude and perception of faculty and Administrators about FDP's in our University and to make suggestions to improve the horizon of existing FDP's.

\section{Objectives}

In order to determine educational needs of the faculty and to identify the priority-areas of faculty members' educational knowledge we conducted this study.

- To assess the attitude and perception of faculty members towards various dimensions of FDPs.

- To assess the attitude and perception of Administrators at SBVU and its constituent Colleges.

\section{Methods}

This is a validated Questionnaire based study. Two sets of questionnaire were prepared. The Questions were assessed by psychometrician. Validation of questionnaire done by senior medical educationists and by many medical education units in the country. Reliability was assessed by Statistical Method- Cronbach's alpha. One set of questionnaire regarding administrators with low score was removed. Institutional Research Council (IRC) and Institutional Human Ethics Committee (IHEC) clearance was obtained FACULTY/2018/09/17.

Final questionnaire was administered to all willing faculty and administrators under the deemed to be university (SBV). Confidentiality was ensured. 
Number of Faculty and administrators in the university are,

Total Number -640

Administrators - 120

Faculty $\quad-520$

\section{Statistical analysis}

Frequency analysis, Comparison tests using Independent samples t-test and graphs with Pie Charts were done. Results were compared at 95\% Confidence level. Entire analysis was carried out in IBM SPSS 19.0 version.

\section{Result}

Total Number of faculty and Administrator's$640(520+120)$.

Total response rate - $\quad 423(65.78 \%)$

Administrators - 74/120(61.66\%)

Faculty $\quad-\quad 349 / 520(67.11 \%)$

\section{Faculty Questionnaire-Statistical Report}

The analysis is done for a questionnaire study in which the sample size is 349 . The statistical analysis such as frequency analysis, graphs with Pie Charts, comparison tests using Independent samples t-test and ANOVA are carried out. The results are compared at 0.05 level of significance and the analysis is done in IBM SPSS 19.0 version.

Table 1 consists the summary statistics in which frequencies of each categories of every parameter under the study. Here the column percentages give the distribution of participants in each parameter of respective categories. Among the participants majority $111(31.8 \%)$ belong to the age category $41-49$ followed by $50-57[105(30.1 \%)]$ and only $63(18.1 \%)$ are of below 40 . With respect to gender distribution, males are around $211(60.5 \%)$ and the rest are females. Majority of the faculty were from clinical departments-169 (48.4\%).

From Table 2 to 6 comparisons are carried out using Independent samples t-test and ANOVA for which the groups considered are Age, Sex, $\mathrm{MCl}, \mathrm{NCl} / \mathrm{DCl}$ and Members of MEU. The observed $p$-value which is less than 0.05 is marked with '*' implies that they are significant. Detail description is there for each table.

It is clear that only roles of teacher and presumed benefits of FDP's are observed to be significant. This significance can be interpreted as, "female participants feel that it is the role of teacher that has to be fulfilled and at the same time they opined that there are some presumed benefits of FDP's. - Table 3

Significance is noticed in items roles of teacher and Newer contents of FDP. The respondents who have attended $\mathrm{MCl}$ have opinionated that it is the role of the teacher to fulfil the FDP and there are some newer content areas that are covered in FDP. Similar interpretation can be drawn where in the respondents who have attended MEU/DEU/NEU workshops reported that newer content areas for FDP should be introduced- Table 4, 5, 6.

\section{Administrator's questionnaire-Statistical report}

Maximum number of Administrators were in the age group of 53-59 yrs. and they were predominantly males. $48 \%$ of faculty who responded to the questionnaire were from the clinical side. There were equal number of administrators who had done Basic Workshop in medical education conducted by Medical Council of India. Majority of the Administrators were members of their respective educational units- Table 7.

Members of respective educational units were in favour of organizing FDP's than nonmembers $(p<0.00)$, and also opined that this will improve the competencies of faculty $(p<0.019)$ - Table 8.

Clinical faculty were more in favour of organizing FDP'S than Non-Clinical faculty ( $p$ $<0.000$ ). Clinical faculty were more in favour of organizing "Specialised FDP's" $(p<0.045)-$ Table 9.

\section{Highlights of the study}

- Only significance is noticed with respect to the respondents who have attended $\mathrm{NCl} / \mathrm{DCl}$ and feel that it is better to organize FDP's.

- Similarly, the respondents who have attended MEU/NEU/DEU felt that FDP's are to be organized and in turn these will develop competencies in faculty.

- With respect to subject, Clinical people feel that FDP's are to be organized and there should be some specialized activities of FDP. 


\section{Comments \& Suggestions}

- The concept of faculty development is evolving and expanding.

- Research skills are becoming a major focus of faculty development.

- Teaching skills are still a prominent aspect of faculty development.

- The institutional environment has become a focus of faculty development.

- Faculty evaluation is an effective approach to faculty development.

- The efficacy of faculty development needs better documentation and the efficacy should be evaluated by students and faculty performance.

\section{Discussion}

Various studies have evaluated many aspects of Health Professions education. The key competencies most highly reported were "plan instructional methods and materials" (Leslie, 2013), "promote retention and knowledge and skills" (Branch, 2009), and "using appropriate teaching strategies for different levels of learners" (Branch, 2009). The most frequent competencies identified were "establish and maintain professional credibility" (Sutkin, 2008), "utilize scholarly and practical approaches in program evaluation" (Swanwick, 2008), "demonstrate teaching competence". Most of these sentiments were echoed by the faculty and administrators in our study also.

Although HPE programs come in many forms, the general consensus is that more robust programs over a longer period of time lead to better results for faculty (Snell, 2000; Techian, 2012). Programs often reflect the needs and the culture of the host institution (Thomas, 2016). Most programs focus on individual faculty, but team-based and institution-focused approaches are growing in popularity (Thorndyke, 2006). Our study also reiterates the same opinion regarding longer term programs which address the faculty needs.

\section{Conclusion}

Professional training programs for faculty members have become essential to higher education institutions in order to be able to compete in this ever-changing world. Faculty development has become well established and has grown into a recognized activity within higher education. Professional development programs produce promising outcomes in the learning and teaching practices and many FDPs have proven effective in developing faculty skills and educational leadership. In this ever-competitive world of education and patient care faculty development constitutes a strategic lever for institutional excellence and quality, and essentially important means for advancing forward institutional readiness to bring in the desired change in response to the ever-growing complex demands facing health professions education. In our study the response rate is only $65.78 \%$, which is of acceptable range for qualitative questionnaire-based study (40$75 \%$ ). It is encouraging to see that majority of faculty feel the necessity for "NEED based" FDP's. Administrators are also of the opinion that Faculty should be competent, and that FDP's go a long way to strengthen the main resource of a Higher education institutions and University.

\section{Acknowledgement}

We would like to thank all the faculty participants who took part in the study.

\section{Conflict of Interest}

The authors declare no conflict of interest.

\section{References}

Branch Jr, W.T., Frankel, R., Gracey, C.F., Haidet, P.M., Weissmann, P.F., Cantey, P., Mitchell, G.A. \& Inui, T.S. (2009) A good clinician and a caring person: longitudinal faculty development and the enhancement of the human dimensions of care, Academic Medicine, 84, 1, pp. 117-125.

Fitzgerald, J.T., Burkhardt, J.C., Kasten, S.J., Mullan, P.B., Santen, S.A., Sheets, K.J., Tsai, A., Vasquez, J.A. \& Gruppen, L.D. (2016) Assessment challenges in competency-based education: A case study in health professions education. Medical teacher, 38, 5, pp. 482-490.

Gaff, J.G. (1975) Toward Faculty Renewal: Advances in Faculty. Institutional and Organizational Development.

Hansen, L.B., McCollum, M., Paulsen, S.M., Cyr, T., Jarvis, C.L., Tate, G. \& Altiere, R.J. (2007) Evaluation of an evidence-based peer teaching assessment program. American Journal of Pharmaceutical Education, 71, 3, pp. 45.

Hauer, K.E., Durning, S.J., Kernan, W.N., Fagan, M.J., Mintz, M., O'Sullivan, P.S., Battistone, M., DeFer, T., Elnicki, M., Harrell, H. \& Reddy, S. (2008) Factors associated with medical students' career choices regarding internal medicine. Jama, 300, 10, pp.1154-1164.

Leslie, K., Baker, L., Egan-Lee, E., Esdaile, M. \& Reeves, S. (2013) Advancing faculty 
development in medical education: a systematic review. Academic Medicine, 88, 7, pp.1038-1045.

Paul, H. \& Howard, F.S. (2006) The role of the teacher student relationship in the formation of physicians. Journal of Internal Medicine, 21, pp.16-20.

Sutkin, G., Wagner, E., Harris, I. \& Schiffer, R. (2008) What makes a good clinical teacher in medicine? A review of the literature. Academic Medicine, 83, 5, pp.452-466.

Snell, L., Tallett, S., Haist, S., Hays, R., Norcini, J., Prince, K., Rothman, A. \& Rowe, R. (2000) A review of the evaluation of clinical teaching: new perspectives and challenges. Medical education, 34,10 , pp.862-870.

Steinert, Y., Mann, K., Centeno, A., Dolmans, D., Spencer, J., Gelula, M. \& Prideaux, D. (2006) A systematic review of faculty development initiatives designed to improve teaching effectiveness in medical education: BEME Guide No. 8. Medical teacher, 28, 6, pp.497-526.

Steinert, Y. (2010) Faculty development: from workshops to communities of practice. Medical teacher, 32, 5, pp.425-428.
Stritter, F.T. (1983) Faculty evaluation and development. Handbook of health professions education.

Swanwick, T. (2008) See one, do one, then what? Faculty development in postgraduate medical education. Postgraduate medical journal, 84, 993, pp.339-343.

Tekian, A. \& Harris, I. (2012) Preparing health professions education leaders worldwide: a description of masters-level programs. Medical teacher, 34, 1, pp.52-58.

Thomas, D.C., Berry, A., Djuricich, A.M., Kitto, S., Kreutzer, K.O.K., Van Hoof, T.J., Carney, P.A., Kalishman, S. \& Davis, D. (2017) What is implementation science and what forces are driving a change in medical education?. American Journal of Medical Quality, 32, 4, pp.438-444.

Thorndyke, L.E., Gusic, M.E., George, J.H., Quillen, D.A. \& Milner, R.J. (2006) Empowering junior faculty: Penn State's faculty development and mentoring program. Academic medicine, 81, 7, pp.668-673.

\section{Appendix - I}

Institutions under Sri Balaji Vidyapeeth are,

- MGMCRI- Mahatma Gandhi Medical College and Research Institute

- SSMCRI- Satya Sai Institute of Medical sciences and Research Institute

- IGIDS- Indira Gandhi Institute of Dental Sciences.

- KGNC- Kasturba Gandhi Nursing College

- AHS- Allied Health Sciences

Administrators - Vice Chancellor, Registrar, Dean Faculty, Dean MGMCRI, Dean SSMCRI, PrincipalKGNC, Principal IGDIS, Principal-AHS, In charge- Medical Education, Director-HPE, All Heads of the departments- 120

Faculty- 520

\section{Appendix - II (Questionnaire details)}

\section{Faculty}

Part I

Demographic details- 9

Part II-

Roles of Teacher (RT) -6

- Information provider in the lecture, and in the clinical context.

- Role model on-the-job, and in more formal teaching settings

- Facilitator as a mentor and learning facilitator

- Student assessor and curriculum evaluator

- Curriculum and course planner

- Resource material creator, and study guide producer 
Factors to be considered-8

- Understand the institutional/organizational culture.

- Determine appropriate goals and priorities

- Conduct needs assessments to ensure relevant programming

- Develop different programs to accommodate diverse needs

- Incorporate principles of adult learning and instructional design

- Offer a diversity of educational methods

- Work to overcome commonly encountered challenges

- Evaluate - and demonstrate - effectiveness

Educational approaches to FDP- 7

- Workshops

- Seminars

- Short courses, and fellowships

- Longitudinal programs

- Peer coaching, mentorship

- Self-directed learning

- ICT -aided instruction

Content areas of FDP-10

- Clinical teaching

- Small group facilitation

- Feedback \& evaluation

- Large group presentations

- Use of IT technology in teaching \& learning

- Question Paper setting and Blueprinting

- How to deliver an effective lecture.

- Use of Simulation based techniques in teaching.

- Role of teacher as guide in dissertation writing and project writing.

- Competence based assessment.

- Management of E portfolios

Newer Content areas of FDP-5

- Leadership \& management skills

- Academic skills \& career management

- Organizational \& curricular development

- Educational scholarship

- Teaching of specific content areas

Job oriented Objectives-4

- I attend FDP to get required scoring

- I attend FDP to break the monotony of job.

- I attend FDP as mandatory requirement for my Promotion

- I attend FDP to enhance my confidence and analytical skills

Obstacles to attend FDP-5

- Mounting Programme Fee restrain me from attending.

- Programmes don not meet our needs.

- Occupied with Departmental work

- Programmes are too short and less hands-on work

- No recognition/Incentives

Part III

Suggestions and comments: 


\section{Administrators}

\section{Part I}

Demographic Data

Part II

Reasons to organize FDP's -9

- Academic Recognition for teachers for their contribution to Teaching.

- Organizing and delivering an effective learning intervention that is relevant for the environment.

- Facilitation of the opportunity for real-life application of acquired knowledge and skills with support.

- Promote development of a sustainable career path with opportunities for growth and advancement.

- Create Agents for change.

- Focus beyond individual teaching effectiveness.

- Develop programs that extend over time.

- Promote workplace learning.

- Foster community development.

Required Competencies of Faculty-13

- Competence in teaching large and small groups

- Competence in teaching in a clinical setting.

- Competence in facilitating and managing learning.

- Competence in planning learning.

- Competence in developing and working with learning resources.

- Competence in assessing trainees.

- Competence in evaluating courses and undertaking research in education.

- Understanding of the principles of education (the intellectual intelligences).

- Appropriate attitudes, ethical understanding and legal awareness.

- Appropriate decision-making skills and best evidence-based education.

- The role of teacher or trainer within the Health Service and the university.

- Personal development about teaching

Specialised FDP activities -8

- Specialized courses (Writing Multiple Choice Questions)

- Orientation workshop for newly recruited faculty

- Training in educational research

- Microteaching sessions for new faculty

- Basic instructional courses for all faculty

- Consultation services as and when required

- Assistance in pursuing educational projects

- Sponsoring interested faculty to pursue a degree program

Additional FDP Activities - 11

- Research methodology

- Question paper setting and Blue printing.

- Assessment and Evaluation

- Clinical research and publication and Ethics.

- Educational leadership.

- Interactive/Integrated teaching

- Teaching of higher cognitive skills

- Managing changes, and mentorship.

- oral examination/Viva Voce

- Simulation based Teaching

- Competency Based Assessment

Part III

Suggestions and Comments: 


\section{Appendix - III (Tables)}

Faculty Questionnaire (Table 1- 6)

Table 1: Summary Statistics

\begin{tabular}{lccc}
\hline \multicolumn{1}{c}{ Characteristics } & Categories & Frequency & Column Percent \\
\hline \multirow{4}{*}{ Age } & $\leq$ & 63 & 18.1 \\
& $41-49$ & 111 & 31.8 \\
& $50-57$ & 105 & 30.1 \\
\multirow{2}{*}{ Sex } & $>58$ & 70 & 20.1 \\
& Male & 211 & $\mathbf{6 0 . 5}$ \\
& Female & $\mathbf{1 3 8}$ & $\mathbf{3 9 . 5}$ \\
\multirow{3}{*}{ Subject } & Preclinical & 68 & 19.5 \\
& Clinical & 169 & 48.4 \\
\multirow{2}{*}{ MCl Course } & Dental & 101 & 28.9 \\
& AHS & 11 & 3.2 \\
\hline Any Other Medical Education & Yes & 210 & 60.2 \\
Course & No & 139 & 39.8 \\
\hline \multirow{2}{*}{ NCl/DCl } & Yes & 126 & 36.1 \\
& No & 223 & 63.9 \\
\hline \multirow{2}{*}{ Member of MEU/NEU/DEU } & Yes & 156 & 44.7 \\
& No & 180 & 51.6 \\
\hline
\end{tabular}

Table 2: Comparison of study parameters with respect to Age

\begin{tabular}{|c|c|c|c|c|c|c|}
\hline Instruments & Age & $\mathbf{N}$ & Mean & $\begin{array}{c}\text { Std. } \\
\text { Deviation }\end{array}$ & F-Value & P-Value \\
\hline \multirow{4}{*}{ Role of teacher } & $<=40$ & 63 & 15.30 & 1.364 & \multirow{4}{*}{1.449} & \multirow{4}{*}{0.228} \\
\hline & $41-49$ & 111 & 15.31 & 1.387 & & \\
\hline & $50-57$ & 105 & 15.59 & 1.412 & & \\
\hline & $>58$ & 70 & 15.17 & 1.464 & & \\
\hline \multirow{4}{*}{$\begin{array}{l}\text { Presumed benefits of } \\
\text { FDPs }\end{array}$} & $<=40$ & 63 & 30.90 & 1.838 & \multirow{4}{*}{2.152} & \multirow{4}{*}{0.093} \\
\hline & $41-49$ & 111 & 31.32 & 1.996 & & \\
\hline & $50-57$ & 105 & 31.29 & 1.925 & & \\
\hline & $>58$ & 70 & 30.67 & 1.991 & & \\
\hline \multirow{4}{*}{$\begin{array}{l}\text { Factors to be } \\
\text { considered for FDP }\end{array}$} & $<=40$ & 63 & 20.81 & 1.848 & \multirow{4}{*}{0.265} & \multirow{4}{*}{0.85} \\
\hline & $41-49$ & 111 & 20.55 & 2.057 & & \\
\hline & $50-57$ & 105 & 20.64 & 2.140 & & \\
\hline & $>58$ & 70 & 20.74 & 1.990 & & \\
\hline \multirow{4}{*}{ Content areas of FDP } & $<=40$ & 63 & 29.79 & 2.106 & \multirow{4}{*}{0.544} & \multirow{4}{*}{0.653} \\
\hline & $41-49$ & 111 & 28.88 & 2.152 & & \\
\hline & $50-57$ & 105 & 29.94 & 2.084 & & \\
\hline & $>58$ & 70 & 29.07 & 2.129 & & \\
\hline \multirow{4}{*}{$\begin{array}{l}\text { Newer concepts of } \\
\text { FDP }\end{array}$} & $<=40$ & 63 & 12.75 & 1.492 & \multirow{4}{*}{0.78} & \multirow{4}{*}{0.506} \\
\hline & $41-49$ & 111 & 12.95 & 1.522 & & \\
\hline & $50-57$ & 105 & 12.83 & 1.503 & & \\
\hline & $>58$ & 70 & 12.61 & 1.497 & & \\
\hline
\end{tabular}

Represents significance at 0.05 level 
Table 3: Comparison between study parameters with respect to sex

\begin{tabular}{lccccc}
\hline \multicolumn{1}{c}{ Parameters } & Sex & Number & Mean & $\begin{array}{c}\text { Std. } \\
\text { Deviation }\end{array}$ & $\begin{array}{c}\mathbf{t} \text { test } \\
\text { (p- value })\end{array}$ \\
\hline Role of teacher & Male & 211 & 15.16 & 1.497 & \multirow{2}{*}{$3.374\left(0.001^{*}\right)$} \\
\hline Presumed benefits of FDP & Memale & 138 & 15.67 & 1.203 & \\
& Female & 138 & 31.55 & 1.864 & \multirow{2}{*}{$3.490\left(0.001^{*}\right)$} \\
\hline Factors to be considered for & Male & 211 & 20.65 & 2.044 & \multirow{2}{*}{$0.089(0.929)$} \\
\hline \multirow{2}{*}{ FDP } & Female & 138 & 20.67 & 2.008 & \\
\hline \multirow{2}{*}{ Newer concepts of FDP } & Male & 211 & 29.11 & 1.987 & \multirow{2}{*}{$1.118(0.264)$} \\
\hline & Female & 138 & 28.86 & 2.294 & \\
\hline
\end{tabular}

Signifies confidence level at 0.05

Table 4: Comparison between study parameters with respect to MCI medical education course

\begin{tabular}{lccccc}
\hline \multicolumn{1}{c}{ Parameters } & Yes/No & N & Mean & $\begin{array}{c}\text { Std } \\
\text { Deviation }\end{array}$ & $\begin{array}{c}\text { t test } \\
\text { (p-value) }\end{array}$ \\
\hline \multirow{2}{*}{ Role of teacher } & Yes & 210 & 15.58 & 1.403 & \multirow{2}{*}{$3.516\left(0.000^{*}\right)$} \\
\hline \multirow{2}{*}{ Presumed benefits of FDP } & Yes & 139 & 15.04 & 1.361 & \\
& No & 139 & 31.02 & 1.994 & \multirow{2}{*}{$0.965(0.335)$} \\
\hline Factors to be considered for & Yes & 210 & 20.70 & 2.110 & \multirow{2}{*}{$0.431(0.667)$} \\
\hline FDP & No & 139 & 20.60 & 1.902 & \\
\hline \multirow{2}{*}{ Content areas of FDP } & Yes & 210 & 28.97 & 2.105 & \multirow{2}{*}{$0.434(0.664)$} \\
\hline \multirow{2}{*}{ Newer concepts of FDP } & No & 139 & 29.07 & 2.135 & \\
\hline
\end{tabular}

Signifies confidence level at 0.05 
Table 5: Comparison between study parameters with respect to Nursing Council of India/Dental Council of India- Medical education course

\begin{tabular}{lccccc}
\hline \multicolumn{1}{c}{$\begin{array}{c}\text { Parameters } \\
\text { NCl/DCl }\end{array}$} & Yes/No & N & Mean & $\begin{array}{c}\text { Std. } \\
\text { Deviation }\end{array}$ & $\begin{array}{c}\text { t test } \\
\text { (p-value) }\end{array}$ \\
\hline Role of teacher & Yes & 156 & 15.43 & 1.396 & $0.871(0.381)$ \\
\hline No & 180 & 15.29 & 1.437 & 1.898 & \\
$\begin{array}{l}\text { Presumed benefits of } \\
\text { FDP }\end{array}$ & Yes & 156 & 31.15 & 1.984 & $0.096(0.923)$ \\
\hline $\begin{array}{l}\text { Factors to be } \\
\text { considered for FDP }\end{array}$ & No & 180 & 31.13 & 1.960 & \\
\hline $\begin{array}{l}\text { Content areas of } \\
\text { FDP }\end{array}$ & Yes & 156 & 20.65 & 2.095 & $0.432(0.666)$ \\
\hline $\begin{array}{l}\text { Newer concepts of } \\
\text { FDP }\end{array}$ & No & 180 & 20.75 & 2.085 & $0.920(0.358)$ \\
\hline
\end{tabular}

Signifies confidence level at 0.05

Table 6: Comparison between study parameters with respect to MCI medical education course

\begin{tabular}{lccccc}
\hline $\begin{array}{c}\text { Parameters } \\
\text { NCl/DCl }\end{array}$ & Yes/No & N & Mean & $\begin{array}{c}\text { Std } \\
\text { Deviation }\end{array}$ & $\begin{array}{c}\text { t test } \\
\text { (p-value) }\end{array}$ \\
\hline Role of teacher & Yes & 133 & 15.30 & 1.456 & \multirow{2}{*}{$0.656(0.512)$} \\
\hline Presumed benefits of & Yes & 133 & 31.29 & 2.033 & \multirow{2}{*}{$1.400(0.161)$} \\
FDP & No & 216 & 30.99 & 1.902 & \\
\hline Factors to be & Yes & 133 & 20.62 & 1.901 & \multirow{2}{*}{$0.273(0.785)$} \\
considered for FDP & No & 216 & 20.69 & 2.105 & \\
\hline Content areas of FDP & Yes & 133 & 29.61 & 1.696 & \multirow{2}{*}{$4.243\left(0.000^{*}\right)$} \\
\hline Newer concepts of & No & 216 & 28.64 & 2.261 & \\
FDP & Yes & 133 & 12.74 & 1.556 & \multirow{2}{*}{$0.721(0.471)$} \\
\hline
\end{tabular}

Signifies confidence level at 0.05 
Table 7: Summary statistics

\begin{tabular}{|c|c|c|c|}
\hline Characteristics & Categories & Frequency & Percent \\
\hline \multirow{5}{*}{ Age } & $<=44$ & 15 & 20.3 \\
\hline & $45-52$ & 25 & 33.8 \\
\hline & $53-59$ & 21 & 28.4 \\
\hline & $>60$ & 13 & 17.6 \\
\hline & Total & 74 & 100 \\
\hline \multirow{3}{*}{ Sex } & Male & 54 & 73 \\
\hline & Female & 20 & 27 \\
\hline & Total & 74 & 100 \\
\hline \multirow{4}{*}{ Subject } & Preclinical & 19 & 25.7 \\
\hline & Clinical & 36 & 48.6 \\
\hline & Dental & 19 & 25.7 \\
\hline & Total & 74 & 100 \\
\hline \multirow{5}{*}{ Designation } & Associate prof & 47 & 63.5 \\
\hline & Professor & 7 & 9.5 \\
\hline & Prof and head & 16 & 21.6 \\
\hline & Dean and prof & 4 & 5.4 \\
\hline & Total & 74 & 100 \\
\hline \multirow{3}{*}{$\mathrm{MCl}$ - Medical education course } & Yes & 39 & 52.7 \\
\hline & No & 35 & 47.3 \\
\hline & Total & 74 & 100 \\
\hline \multirow{3}{*}{$\mathrm{NCl} / \mathrm{DCl}$ - Medical education course } & Yes & 30 & 40.5 \\
\hline & No & 44 & 59.5 \\
\hline & Total & 74 & 100 \\
\hline \multirow{6}{*}{ Any Other Medical education course } & FAIMER/MHPE & 3 & 4.1 \\
\hline & NO & 34 & 45.9 \\
\hline & NTTC Jipmer & 2 & 2.7 \\
\hline & PGDHPE & 3 & 4.1 \\
\hline & YES & 32 & 43.2 \\
\hline & Total & 74 & 100 \\
\hline \multirow{3}{*}{ Member of MEU/NEU/DEU } & Yes & 42 & 56.8 \\
\hline & No & 32 & 43.2 \\
\hline & Total & 74 & 100 \\
\hline
\end{tabular}


Table 8: Comparison between study parameters with respect to member of MEU/NEU/DEU

\begin{tabular}{|c|c|c|c|c|c|}
\hline Parameters & Yes/No & $\mathbf{N}$ & Mean & $\begin{array}{c}\text { Std } \\
\text { Deviation }\end{array}$ & $\begin{array}{c}\text { t test } \\
\text { (p-value) }\end{array}$ \\
\hline \multirow{2}{*}{$\begin{array}{l}\text { Reasons why FDP to } \\
\text { be organized }\end{array}$} & Yes & 42 & 21.190 & 1.517 & \multirow{2}{*}{$3.732\left(0.000^{*}\right)$} \\
\hline & No & 32 & 22.375 & 1.211 & \\
\hline \multirow{2}{*}{$\begin{array}{l}\text { Competency of faculty } \\
\text { needed }\end{array}$} & Yes & 42 & 33.57 & 2.307 & \multirow{2}{*}{$2.400\left(0.019^{\star}\right)$} \\
\hline & No & 32 & 32.16 & 2.760 & \\
\hline \multirow{2}{*}{ Benefits of FDP } & Yes & 42 & 40.93 & 1.800 & \multirow{2}{*}{$1.006(0.319)$} \\
\hline & No & 32 & 40.44 & 2.271 & \\
\hline \multirow{2}{*}{$\begin{array}{l}\text { Specialized activities } \\
\text { of FDP }\end{array}$} & Yes & 42 & 19.81 & 1.838 & \multirow{2}{*}{$1.596(0.115)$} \\
\hline & No & 32 & 20.44 & 1.544 & \\
\hline \multirow{2}{*}{$\begin{array}{l}\text { Additional FDP } \\
\text { activities }\end{array}$} & Yes & 42 & 26.62 & 1.975 & \multirow{2}{*}{$1.292(0.201)$} \\
\hline & No & 32 & 27.28 & 2.331 & \\
\hline
\end{tabular}

Signifies confidence level at 0.05

Table 9: Comparison between study parameters with respect to subjects

\begin{tabular}{lccccc}
\hline \multicolumn{1}{c}{ Parameters } & Subject & N & Mean & $\begin{array}{c}\text { Std. } \\
\text { Deviation }\end{array}$ & $\begin{array}{c}\text { F test } \\
\text { (p- value })\end{array}$ \\
\hline $\begin{array}{l}\text { Reasons why FDP to be } \\
\text { organized }\end{array}$ & Preclinical & 19 & 20.5263 & 1.3068 & \\
$\begin{array}{l}\text { Competency of faculty } \\
\text { needed }\end{array}$ & Clinical & 36 & 22.2500 & 1.2042 & $10.384\left(0.000^{*}\right)$ \\
\hline \multirow{2}{*}{ Benefits of FDP } & Dental & 19 & 21.8421 & 1.6077 & \\
& Preclinical & 19 & 33.11 & 2.923 & \\
& Clinical & 36 & 32.53 & 2.197 & $1.173(0.315)$ \\
Specialized activities of & Dental & 19 & 33.63 & 2.910 & \\
FDP & Preclinical & 19 & 41.21 & 1.512 & \\
& Clinical & 36 & 40.83 & 1.781 & $1.872(0.161)$ \\
& Dental & 19 & 40.00 & 2.687 & \\
Additional FDP activities & Preclinical & 19 & 19.58 & 2.036 & \\
& Clinical & 36 & 19.92 & 1.481 & $3.327\left(0.045^{\star}\right)$ \\
\cline { 2 - 5 } & Dental & 19 & 20.89 & 1.663 & \\
\cline { 2 - 5 } & Preclinical & 19 & 26.21 & 2.275 & \\
& Clinical & 36 & 27.39 & 1.695 & $2.069(0.134)$ \\
\hline
\end{tabular}

Signifies confidence level at 0.05 